\title{
Grishunina J. \\ Analysis of crisis in the automobile building capital in the 20th century
}

Financial University under the Government of the Russian Federation

Financial University under the Government of the Russian Federation

doi: $10.18411 / \mathrm{l}-05-2019-84$

idsp: ljournal-05-2019-84

Scientific adviser: Bych E.I.

\begin{abstract}
The article is devoted to the analysis of the phenomenon in the financial and economic aspect and the consideration of the prospects for further developments.

The author considers the reasons for decline of Detroit, finds the main reasons and searches ways of further development.

The article gives the reader information about how Detroit can get out of the crisis. Much attention is paid to company Ford as a major investor who can save the city's economy.

Factors have been identified as a result of the work. This may prevent a similar crash in the future. Therefore, this article is of interest not only for students, but also for academics.

Key words: bankruptcy, Detroit, industry, crisis, financial indicator, investment.
\end{abstract}

\footnotetext{
Аннотация

Статья посвящена анализу финансово-экономического явления и рассмотрению перспектив его дальнейшего развития.

Автором статьи были рассмотрены причины упадка Детройта, найдены основные из них и предложены пути дальнейшего развития событий.

Благодаря статье, читатель может получить информацию о том, как Детройт может выйти из кризиса. Большое внимание уделяется компании Ford как крупному инвестору, который может спасти экономику города.

В результате проделанной работы были определены факторы, способные предотвратить подобный сбой в будущем. Поэтому данная статья может быть интересна не только для студентов, но и для научных деятелей.

Ключевые слова: банкротство, Детройт, промышленность, кризис, финансовый показатель, инвестиции.
}

In 1973 in the conditions of oil crisis the products of "the big three" could not compete with production of Europe and Japan which was more economic. In 1979 the energy crisis became one more blow which only financial crisis of 2008-2009 could surpass. After closing of the plants large-scale reduction followed and families began to leave Detroit.

Emigration reached the peak twice: in 1980 and 2000. Inappropriate infrastructure became one of city causes of death. At some point the place for movement on automobile transport which extended for achievement of the goal - "A separate car - to each family" did not begin to be enough. Due to the fact that rich inhabitants began to leave the residence, various shops began to be closed because of the absence of buyers. The small and average businesses, industrial shops and the plants had no demand anymore [2].

By $201323.1 \%$ of the population lost the jobs, at the same time $36.4 \%$ appeared to be below the poverty line. Now less than 680 thousand people live in Detroit. The former capital of automotive industry promptly turned into the ghost town.

In 2013 in the city bankruptcy was declared due to impossibility of repayment of accounts payable which was $\$ 18.5$ billion. However, the procedure was completed in December (2014), then all efforts were directed to improve the situation and attract investors [4]. 
During this period 85 thousand thrown real estate objects were revealed. In this regard in 2014 the program for demolition of a half of buildings which in the general set would make about $25 \%$ of all territory of the city was developed and adopted.

On July 18, 2013 the government of Detroit officially declared that the city couldn't pay bills anymore. Existence of the policy not capable in time to react to actions of criminals, and the ambulance which is not saving life of people indicates trouble of this municipality to us. There appears the following question: if the capital of automobile industry was in the certain state whether then it is fair to speak about its bankruptcy?

The employees of Fund for Peace who are annually counting the Index of the incapacitated states applied the developed models and concluded that assessment of capacity of the cities differs from methodology of assessment of the states [3]. However, by a certain comparison of data, it is possible to make the following table:

Table No. 1

"Rating by the index of incapacity of the states".

\begin{tabular}{|c|c|}
\hline Name of the state & The index is higher, the position of the state is worse. \\
\hline Somalia & 113,9 \\
\hline Democratic Republic of the Congo & 111,9 \\
\hline Brazil & 62,1 \\
\hline Kuwait & 59,6 \\
\hline "Detroit as state" & $(128$ th place $)$ \\
\hline Mongolia & 57,8 \\
\hline Romania & 57,4 \\
\hline The USA & 33,5 (159th place) \\
\hline
\end{tabular}

If to compare Detroit to other states, then its general provision is better, than in Brazil or Kuwait, and is very far from an economic situation in such countries as Somalia and Congo.

The problem of departure of people and brain drain had a serious impact. Its assessment was equated to 6.5. In the USA this indicator is 1.0 units. Also, Detroit corresponds to South Sudan 6.5 and concedes to Syria 6.2 according to research Fund for Peace.

Besides, economic contraction and the increased level of poverty following it are characteristics of the former capital of mechanical engineering. The efficiency of Detroit managed to became a legend, but by 2013 the income per capita made only 15.261 dollars. Experts of Fund for Peace claim that the considered indicators limit the states in an opportunity to financially provide the population and functioning of the country, at the same time creating a gap between poor and rich segments of the population. Thus, the city receives 6.5 , appearing practically flush with Syria 6.4.

In addition, the state must have monopoly for using force legitimately. In Detroit the negative trend is traced: extremely slow reaction of law enforcement agencies at high crime rate and application of "mob killings" by the voluntary organizations for protection of law and order. Now the indicator "efficiency of the device of safety" on which the USA receives 2.2 and Detroit is estimated in 5.5 and is on an equal basis with Sierra Leone and Rwanda.

Despite this fact, the city keeps the positions in the sphere of "service of the population" and "human rights protections", making a set of efforts for restoration of infrastructure and change of an economic situation for the best.

One of the main reasons for decline is that automobile industry of the USA began to lose a possibility of sale. For the last 20 years in the American market the large volume of foreign competitive products appeared, for example, the European, Japanese and Chinese models were more power-intensive, not less qualitative, but were on sale cheaper. So, crisis of production and sale together with outflow of the population formed a chain of events, relationships of cause and effect resulted in bankruptcy of Detroit. 
Statistics can reflect a present condition of Detroit: for the last decade the population fell from 1,800 to 700 thousand people; level of crime and crime increased in 5, 5 times in comparison with an average value across the USA. For elimination of the problems connected with arrangement of the city, the conditions of buildings in Detroit were estimated - 40 thousand buildings were the subject to demolition. But municipal authority's funds were not revealed (Elimination of the central station and large automobile plants would require nearly $\$ 1.15$ billion).

Therefore, negotiations with the federal government, with a set of private companies and owners who could finance demolition of the abandoned buildings could become a necessity. Then there would be a question of operation of the territory which is presumably cleaned under construction of parks.

According to the deputy director of Institute of the USA, foreign investments can become the only rescue for the city. The firms of Europe, Japan and China which with ease won the market of the United States are capable to make Detroit the capital of the industry by contributions.

On July 1, 2018 the management of Ford announced desire of reconstruction of the building of the former station in the research center which can cost the organization 2 billion dollars. According to experts, similar action is capable to draw attention of developers and scientists that will help to restore infrastructure of the former automobile capital [5].

Share price of Ford decreases over the last 5 years (2014-2019), but financial performance steadily worsens. It can be seen in graph No. 1. In this regard, the CEO of Ford James Hakett approved the plan about cut in expenditure of the organization to 25 billion dollars by 2020 which will help the organization to revitalize an operational element [7].

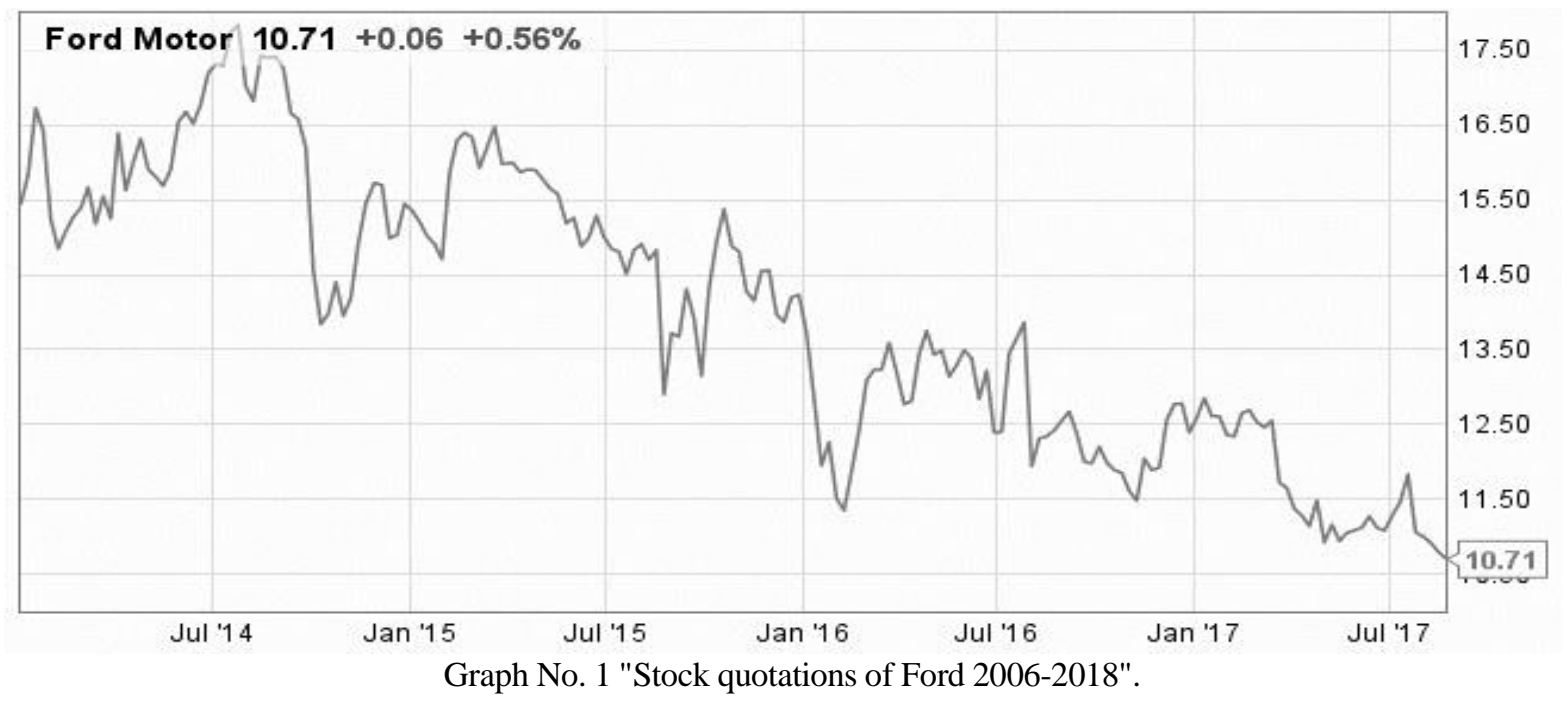

The chairman of the board of directors Bill Ford made a statement that the additional capital was not allocated by the government of the United States, at the same time a part of the means which are earlier allocated for repair of the headquarters located in the suburb of Detroit will be used. The decision on reconstruction was made in the detailed analysis of expenses and risks which revealed benefit of implementation of activity in Detroit. Financial stability of the Ford Motor company is on borderline [1].

However, acquisition of the abandoned building in Detroit can become a key to modernization of the company Ford, which invests funds in the perspective directions of development of the transport systems of the future. The American businessmen are convinced of 
expediency of investment into development of business of Detroit [6]. Actions of the founder of the Quicken Loans company Dan Gilbert who allocated 5.6 billion dollars for repair and restoration of buildings in the center of the abandoned city for involvement of young and educated specialists can become the most successful example. Thus, creation of the research center in the most depressive city of the USA gives the chance of creation of the unique urban environment suitable on generations of millennials. Introduction of the import duties on import of foreign cars (for example, from Mexico) could promote restoration of the city. Such giants as Ford, General Motors and Toyota have set of opportunities to resume production in the territory of the United States promoting growth of economy of Detroit. It occurs within new presidential policy. Now the automobile building capital of the XX century remains "blank sheet" for realization of set of projects.

$* * *$

1. Gray D.S., Grey N.V. Coefficients of cash flows of the company: assessment, analysis and practical application//Institute of problems of management of V.A. Trapeznikov of the Russian Academy of Sciences, National research university "Higher School of Economics" (Higher School of Economics National Research University), 20.12.16; Pete Saunders, Detroit, Five Years After Bankruptcy // Forbes, Jul 19, 2018.

2. Magazine "Foreign Policy". URL: https://inosmi.ru/world/20130721/211141783.html (Date of the access 13.03.2019)

3. URL: https://varlamov.ru/1411471.html (Date of the access 13.03.2019)

4. URL: https://bf.arsagera.ru/ford_motor_company/itogi_2018_goda/ (Date of the access 10.03.2019)

5. URL: https://ru.investing.com/equities/ford-motor-co-financial-summary (Date of the access 9.03.2019)

6. URL: https://www.bloomberg.com/search?query=Detroit (Date of the access 10.03.2019)

7. URL: https://ru.investing.com/equities/ford-motor-co-financial-summary (Date of the access 10.03.2019). 